\title{
ASSOCIATION OF THALASSEMIA MAJOR WITH CONSANGUINEOUS MARRIAGES IN THE PROVINCE OF KHYBER PAKHTUNKHWA- A CASE CONTROL STUDY
}

\author{
HAYAT MUHAMMAD KHAN ${ }^{1}$, ZIA UR REHMAN ${ }^{2}$, MOHAMMAD AMJAD ${ }^{3}$, \\ NAEEMULLAH ${ }^{4}$, MUHAMMAD NAEEM $^{5}$ \\ 1,2,3,5. Department of Community Medicine Khyber Medical College Peshawar. \\ 4. Department of Community Medicine Saidu Medical College Swat.
}

\begin{abstract}
BACKGROUND: Beta Thalassemia is the commonest genetic disorder worldwide. It is one of the types of hemoglobinopathies which results from either deficient synthesis or complete loss of one of the Beta chains of hemoglobin. Children with Thalassemia major or minor might have defective genes in their parents. Consanguineous marriages are important risk factors in transmission of thalassemia from parents to their children. So avoidance of cousin marriages can prevent thalassemia in children. Premarital counseling with couples having thalassemia trait can be an important step in prevention of thalassemia. Pre-marriage chromosomal studies can be useful in prevention of thalassemia.

OBJECTIVE: The main objective of the study is to establish an association of cousin marriages with thalassemia major in the Pathan community of Khyber Pakhtunkhwa.

CONCLUSION: Thalassemia is the commonest genetic disorder in the world. It is more prevalent in those families where cousin marriages are frequent. The same is situation in the province of KPK where prevalence of cousin marriages is more than $55 \%$.

RESULTS: Total 180 cases and controls were analyzed with 1:1 ratio. Out of the total $109(60 \%)$ were male children while $71(40 \%)$ were female children. Father literacy rate was $54 \%$ and mother literacy rate was $18 \%$. $66 \%$ parents of the cases were knowledgeable about the disease. Association of cousin marriages with thalassemia major was significant with an odds ratio of 2.25 (CI 95\%, P value 0.05 ). Rest of the variables had no significant association with thalassemia major.
\end{abstract}

Key words: Thalassemia, Consanguineous Marriages

\section{INTRODUCTION}

Beta thalassemia is the commonest genetic disorder worldwide ${ }^{(1)}$. It occurs with a particular high frequency in a broad belt extending from Mediterranean basin through Middle east, Indian subcontinent, Burma and Southeast Asia ${ }^{(2)}$. There are estimated 60-80 million carriers of thalassemia worldwide. Each year 60,000 beta Thalassemia carriers are born. Approximately $1.5-3 \%$ of the world population is suffering from beta thalassemia ${ }^{(3)}$. About $50 \%$ of thalassemia trait in the world is in South East Asia $^{(4)}$. 60,000 children in Pakistan are suffering from thalassemia. Approximately $5 \%$ of our population is carrier of thalassemia ${ }^{(5)}$. Prevalence of thalassemia in Khyber Pakhtunkhwa Province is approximately $4 \%$ (two million) $)^{(5)}$. Countries such as Pakistan and India are observing large increase in thalassemia cases as these countries have non regular premarital counseling and screening programs ${ }^{(6)}$.

Beta thalassemia major has high incidence rate $(>18 / 1000)$ in British Pakistani community living in United Kingdom but their knowledge of genetic disorders associated with consanguineous marriages is limited ${ }^{(7)}$. Although there are many benefits of premarital testing, it is not acceptable in some communities for various reasons like legal, religious, educational and cultural factors ${ }^{(8)}$. The success of these programs depends on adequate religious support, 
government policies, health education and counseling $^{(9)}$. If both the parents are carriers of thalassemia, transmission to their children can be prevented using CVS technique which has outstanding sensitivity ${ }^{(10)}$. Peripheral blood smear examination and red cell indices are effective and valuable tools for screening and diagnosis of thalassemia ${ }^{(11)}$.

\section{MATERIALS AND METHODS}

Study Design: It was a case control study. Cases were children with thalassemia major confirmed by $\mathrm{Hb}$ electrophoresis. Controls were children without thalassemia attending OPD for some other problem.

Setting: Cases were selected from Frontier foundation blood services which is a charity organization located in Tehkal on University road Peshawar. Patients from all over the province are referred with a major contribution from Khyber teaching hospital which is located at three kilometer from this center.

Duration: The study was conducted in 06 months.

Sample Size: 90 cases and 90 controls were selected.

Sampling technique: Cases were selected among those children brought to frontier foundation for transfusion referred from Khyber teaching hospital Peshawar children OPD as controls were also selected from the same OPD. For each case, a control was selected. Controls were matched to the cases in term of their numbers and approximate age in years.

Variables: exposure variables include parents with cousin marriages and without cousin marriages. Outcome variables were children with thalassemia major and children without thalassemia major.

Inclusion criteria: All the children with thalassemia major belonging to the province Khyber Pakhtunkhwa were included in the study.
Exclusion criteria: Parents of cases and controls unwilling to give interview were excluded. If Cases and controls gave mixed picture of thalassemia major and minor were also excluded from the study.

Data analysis: Data was analyzed using SPSS version 16.

\section{RESULTS}

Equal number of cases and controls (i.e 90: 90) were analyzed for different variables like gender, father and mother education level, and parent's knowledge of thalassemia and cousin marriages. Risk was estimated using Odds ratio.

Table: 1: Breakup of variables among cases and controls

\begin{tabular}{|c|c|c|c|c|}
\hline Variables & & Cases & Controls & Total \\
\hline \multirow[t]{2}{*}{ Gender } & Males & 56 & 53 & 109 \\
\hline & Females & 34 & 37 & 71 \\
\hline \multirow[t]{2}{*}{$\begin{array}{l}\text { Father } \\
\text { education }\end{array}$} & $\begin{array}{l}\text { SSC \& } \\
\text { above }\end{array}$ & 40 & 58 & 98 \\
\hline & $\begin{array}{l}\text { Below } \\
\text { SSC }\end{array}$ & 50 & 32 & 82 \\
\hline \multirow[t]{2}{*}{$\begin{array}{l}\text { Mother } \\
\text { education }\end{array}$} & $\begin{array}{l}\text { SSC \& } \\
\text { above }\end{array}$ & 19 & 13 & 32 \\
\hline & $\begin{array}{l}\text { Below } \\
\text { SSC }\end{array}$ & 87 & 61 & 148 \\
\hline \multirow{2}{*}{$\begin{array}{l}\text { Parents } \\
\text { Knowledge } \\
\text { of } \\
\text { Thalassemia }\end{array}$} & No & 59 & 49 & 108 \\
\hline & Yes & 31 & 41 & 72 \\
\hline
\end{tabular}

Table 2: Consanguinity of parents

\begin{tabular}{|l|l|l|l|}
\hline $\begin{array}{l}\text { Consanguinity } \\
\text { Of parents }\end{array}$ & Cases & Controls & Total \\
\hline First cousins & 55 & 37 & 92 \\
Non cousins & 35 & 53 & 88 \\
\hline Total & 90 & 90 & 180 \\
\hline
\end{tabular}


Odds ratio (OR) of all the variables except consanguineous marriages of the parents was nonsignificant. OR of father education, mother education and parent knowledge of thalassemia was $1.30,0.54$ and 0.112 while upper and lower limit was $0.727-2.35,0.249-1.45$ and 0.041 0.345 respectively. $\mathrm{OR}$ of consanguinity of the parents was 2.25 with confidence limits of $1.24-$ 4.08 at $95 \% \mathrm{CI}$.

\section{DISCUSSION}

In our case control study in Peshawar, the main aim was to test the hypothesis which proposed that cousin marriage is a major cause of thalassemia major in children born to these parents with consanguineous marriage. The study was long planned when the results of a study on consanguineous marriages in Israel was published ${ }^{12}$. There was a strong possibility that $1^{\text {st }}$ cousin marriages would be a major risk factor in thalassemia major cases because of high prevalence rate of thalassemia in the province of Khyber Pakhtunkhwa. In our study a strong association was found between cousin marriages and thalassemia major with an Odds ratio of 2.25 (CI 95\%, $\alpha=0.05$ ). This odds ratio shows that the association of thalassemia major and cousin marriages is significant. Significant association reflects the results of an international study which show that 21-50 \% of marriages in Muslim societies are consanguineous in nature to maintain their cultural and family stability in their offspring ${ }^{13}$. In our study exposure rate (cousin marriages) both in cases and controls was $51 \%$.

We looked at the educational level of parents, gender of both cases and controls, age of cases and controls and knowledge of parents of cases and controls about premarital screening and counseling for thalassemia as well as chorionic villous sampling (CVS) during pregnancy if they have any future planning for more children. None of these variables had significant association with thalassemia major.
The first ever thalassemia prevention project in Pakistan was established in Peshawar in 2005. It is meant for awareness in public using mass media like TV, Radio and newspapers. There is only limited data about thalassemia in the province. The project is working only in settled areas but the tribal areas are ignored. In our study $94 \%$ of parents of controls were ignorant about transmission of genetic disorders like thalassemia. In cases, $64 \%$ of the parents had some idea about transmission of genetic disorders. So for the knowledge about genetic diseases like thalassemia are very limited in general public which according to the results of a study which was done on British Pakistanis ${ }^{14}$. Even in such a highly educated societies there is lack of lack of understanding of the genetic disorders which are mainly spread through intercousin marriages. Educational programs are quite effective in the prevention of thalassemia as observed in Iran where improvement has been observed in the awareness level of general public after introduction of educational programs in the society ${ }^{15}$. Prenatal diagnosis of thalassemia major in the $1^{\text {st }}$ trimester using Chorionic Villous Sampling (CVS) technique can be an effective tool in the prevention of thalassemia major. Once prenatal diagnosis is made, pregnancy can be terminated in the $1^{\text {st }} 120$ days as this line is evident from the Holy Quran and Hadith ${ }^{16}$. So the Muslims, keeping in view their religion, culture and ethical consideration, can practice early diagnosis and termination of pregnancy for the prevention of thalassemia major in their offspring.

\section{CONCLUSION}

Thalassemia is the commonest genetic disorder in the world. It is more prevalent in those families where cousin marriages are frequent. The same is situation in the province of KPK where prevalence of cousin marriages is more than $55 \%$. There is strong association of cousin marriages with thalassemia major cases in our province. Awareness among general public about the disease is almost negligible. Private organizations play important role in the 
provision of blood services to thalassemia patients. Counseling for non-cousin marriages and pre-marriage chromosomal studies can prevent thalassemia transmission in children.

\section{REFERENCES}

1. Malik S, Syed S, Ahmed N.Complications in transfusion-dependent patients of B-thalassemia major.Pak J Med Sci Jul - Sep 2009; 25(4):678-82.

2. Kremastinos T D, Farmakis D, Aessopos A, Hagalis G, Hamodraka E, Tsiapras D, Karen A. Beta Thalassemia cardiomyopathy: History, present consideration and future perspective. Circ Heart Fail, May 2010; 3: 451-458

3. U1 ain Q, Ahmed L,Hassan M, Rana S M, Jabeen F. Prevalence of beta thalassemic patients associated with consanguinity and Anti HCV Antibody positivity- A cross sectional study. Pakistan J.zool. vol 43(1) pp 29-36, 2011.

4. Niazi M, Tahir M, Raziq F, Hameed A. Usefulness of red cell indices in differentiating

microcytichypochromic anemia. Gomal Journal of Medical Sciences 2010; 8(2): 41-43.

5. Pakistan Observer Saturday September 07, 2013. Intercousin Marriges is the major cause of Thalassemia major; a report presented by Lt. Gen. (R) Moeen ud din Haider (president Pakistan Thalassemia federation) in $8^{\text {th }}$ national thalassemia conference at RIPHAH International University $\mathrm{Al}$ mizan campus Peshawar road Rawalpindi on Sunday 06, May 2012.

6. Arif F, Fayyaz F, Hamid A. Awareness among parents of children with Thalassemia major. J Pak Med Assoc Nov 2008; 58(11):621-4.

7. Bullock C, Khalid F N. Health issues related to customary consanguineous marriage among British Pakistanis. Health promot. Int. (1995) 10 (3): 209-217.

8. Fahad M, Alswaidi and Sarah J. Premarital screening programs for Hemoglobinopathies, HIV and factors affecting their success. J Med Screen, Mar 2009; 16: $22-28$.

9. Ahmed A. Assessment of level of awareness and utilization of treatment options in Thalassemic children. Pak Paeds J Dec 2006; 30(4): 188-92.

10. Syed S, Shafi F, Yasmeen L, Noreen H, Chaudry R. Pre-natal diagnosis of beta Thalassemia by Chorionic villous Sampling. J Rawal Med Coll Jul- Dec 2009; 13(2): 83-5.

11. Aman A, Zehra N, Haider G, Anjum F, Rani S, Munir A A. Role of mean corpuscular volume as screening test for Thalassemia in pregnant women at Irsa University. Pak J Med Sci April - June 2010; 26(2): 390-3.

12. Raz A, Atar M. Cousin marriage and premarital carrier matching in a Bedouin community in Israel: attitudes, service development and educational intervention. J Fam Plann Reprod Health Care 2004; 30: 49-51.

13. Yunis K, Rafei R E, Mumtaz G. International Perspective Consanguinity: Perinatal outcomes and prevention - A view from Middle East. NeoReviews February 1 2008; vol. 9 (2): 59-65.

14. Darr A, Modell B. The frequency of consanguineous marriage among British Pakistanis. J Med Genet March 1998; 25: 86-92.

15. Hassanpour A, Dekhordi, heydareiad S. Enhancement of parent's awareness about beta-thalassemia major disorder through two educational programs. Pak J Med Sci April - June 2008; 24(2): 283-86.

16. Imran I. Prevention of Thalassemia in Pakistan. Nishtar Medical Journal April - June 2009; 1(2): 1-3
CORRESPONDENCE ADDRESS:

Dr. Hayat Muhammad Khan,

MBBS, MPH (KMU), Fellowship in Global Health (USA),

Demonstrator, Community Medicine Department Khyber Medical College Peshawar

Cell: 03339132404 